\title{
腎透析患者の骨変化について
}

鹿児島大学整形外科 (主任: 宮崎淳弘教萌)
宮 崎 淳 弘・酒 包
田 中 源 郎・矢 野 良 英
今給黎 尚 典・富 村 吉十郎
前 原 東 洋

第 2 内科

尾 辻 義 人・前田
原 田

\section{Bony Alteration in the Patients with Renal Failure during Dialysis}

By

\author{
A. Miyazaki, T. Sakou, M. Tanaka,Y. Yano, \\ T. Imakyure, K. Tomimura, \& T. Maehara \\ Department of Orthopedic Surgery, Faculty \\ of Medicine, Kagoshima University \\ Y. Otsuzi, T. Maeda, R. Harada, \& T. Murakami \\ Department of 2nd Internal Medicine, Faculty of Medicine. \\ Kagoshima University
}

\begin{abstract}
Roentogenographic observation has been made on bony changes in twenty-seven patients with renal failure during dialysis, and histopathological examination of bone specimens was carried out in six cases.

Subperiosteal resorption of bone and radiolucent cyst-like lesion as seen in hyperparathyroidism were present in seventeen patients, focal and extensive demineralisation in seven, ricket-like lesion in five, periosteal thickening in two and ostesclerosis in one. Demineralisation of bone was predominantly found in the specimen from spine and femur in 5 cases. Bone biopsy of a rib with Villanueva tetrachrome staining (Frost) showed the evidence that the activity of bone formation and bone resorption were raised to a greater degree and osteoid seam markedly increased in as well as width.
\end{abstract}

慢性腎不全のある場合，骨変化の起とるととは古く より知られており, renal osteodystrophy と呼ばれ ているが，従来余り注目されていないようである. 近年腎不全患者に透析療法が実施され延命効果がもた らされており，てれにともないカルシウム代謝異常 に基く骨変化や異所性石灰沈着などの合併症が起て るととが報告されている．今回，われわれは昭和 46 年以来透析療法を受けている腎不全の症例の骨変化に ついて，X線学的変化を観察するとともに, 屍体解剖 5 例と透析中の一症例の骨生検を行ない, 組織学的に
検索を行なったので若干の文献的考察を加えて報告す る.

症例：X線学的変化を観察した症例は 27 例で, 男 子 20 例, 女子 7 例となっており, 年令別では最少 21 才，最長 69 才に及び， 20 才代が 7 例， 30 才代が 5 例, 40 才代が 9 例, 50 才代が 3 例, 60 才以上が 3 例 であった。

䍜患期間 : 1 年未満 3 例, 1 年以上 2 年未満 1 例, 2 年以上 3 年未満 6 例, 3 年以上 7 例で大部分の症例 は 2 年以上を経過している。 
血清アルカリフォスフォターゼ 血清リン

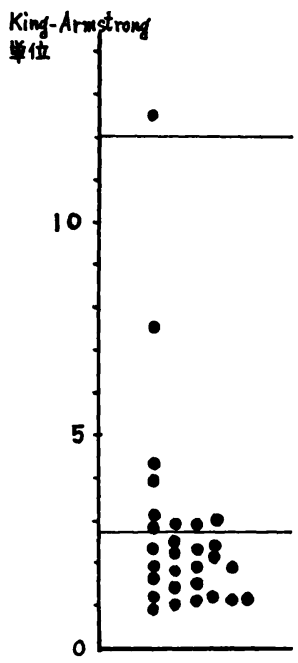

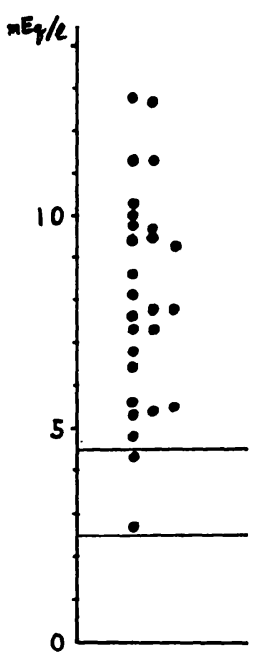

血清カルシウム

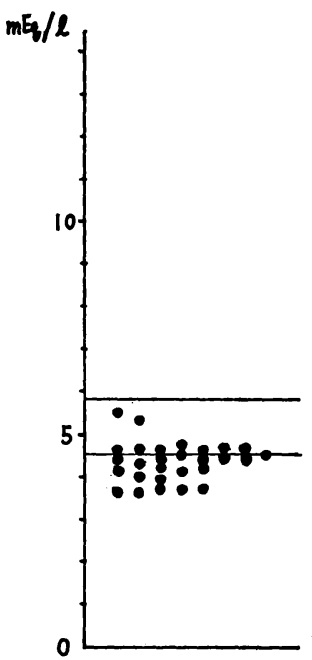

表 1 透析 年 数

\begin{tabular}{|c|c|c|}
\hline $\begin{array}{l}6 \text { 力月未満 } \\
6 \text { 力月上 } \\
11 \text { 年以上 } \\
2 \text { 年以上 }\end{array}$ & $\begin{array}{l}1 \text { 年末満 } \\
2 \text { 年末満 } \\
3 \text { 年末満 }\end{array}$ & $\begin{array}{l}7 \\
7 \\
5 \\
8\end{array}$ \\
\hline \multicolumn{2}{|c|}{ 計 } & 27 \\
\hline
\end{tabular}

表 $2 X$ 線所見

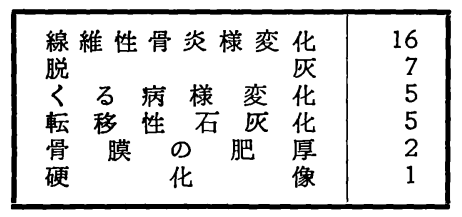

图 1

透析年数：透析年数は 6 力月未満 7 例, 6 力月以上 1 年末満 7 例, 1 年以上 2 年未満 5 例, 2 年以上 3 年 未満 8 例で, 平均 15 力月であつた（表1）.

生化学検査：透析開始後の血清カルシウム值は正常 值以下のものが多いが，血清燐は大部分のものが高い 值を示し, 正常範囲にあるものは少なかった. アルカ リフォスファターゼ值は大部分の症例において, 低い 值を示した（図1）.

次にX線学的骨変化は, 表 2 亿見られる如く線維性 骨炎样変化をみるものが 16 例で，そのうち骨膜下吸 収が 14 例と多くみられ，斑紋状吸収，顆粒状吸収等 もみられた，局所的あるいは全身的に骨脱灰のみのも の 7 例, くる病様変化は 5 例で, 長管骨の変形や骨改 変周の出現もみられた。転移性石灰化は 5 例にみら れ，その中には広汎に血管の石灰化をきたした症例も あった，そのほか骨膜の肥厚が 2 例, 骨硬化が 1 例に 認められた（図 $2 ， 3$ ）てれ等の変化は罹患年数や透 析年数に比例するようである.

組織学的所見: 組織学的には骨脱灰の所見が著明 で, 骨皮質は菲薄化し, 骨梁の辺縁は不規則で骨梁の 細小化もみられる.また骨膜下吸収もみられる.一部 に骨組織の染色性の低下している部分もみられ，硝子 椂変化や線維化の所見も軽度に認められた。

次に透析中の症例の第 11 肋骨の biopsy を行ない 末脱灰研磨標本を作製し，Frostによる osteochrome
染色を行なった。乙の症例は腎不全発症後 2 年 9 力 月, 透析年数 2 年 1 力月でX線所見は骨膜下吸収之脱 灰が著明にみられた．組織学的には吸収腔と osteoid seam を伴った osteon が異常に多く, 骨新生と骨吸 の増進せる状態がみられた。 また osteoid seam の巾 が $20 \mu$ 乃至 $30 \mu$ に増加しており, 石灰化の障害が 認められた（図4).

肋骨横断表面積に対する骨皮質の面積の割合は 0.43 であり, Frost の standard を参照すると osteoporosis の所見はないようである.

考按：慢性腎不全が長期にわたり存続すると，全身 性の骨変化を招来するととは古くより知られている が, 多くの人々の興味を惹起するに到らず，また本邦 に於いても報告は極めて少ない.

腎系球体の障害を 基盤として起とる骨障害は azotaemic osteodystrophy あるいは renal osteodystrophy と呼ばれ, 血清 $\mathrm{Ca}$ 濃度の低下, 血清 $\mathrm{P}$ 濃 度の上昇, 血清アルカリフォスファターゼ值の上昇が みられ, クル病性あるいは骨軟化症性変化, 副甲状腺 機能亢進及び骨硬化等の多彩な病像を呈するとされて いる.

てれ等の骨病変の発生機序に関しては不明な点が多 い. 血清 $\mathrm{Ca}$ 濃度の低下に基く二次的副甲状腺機能六 進とビタミン D代謝異常, 即ち活性型であるビタミン $\mathrm{D}_{3}$ への転換の阻害が重要因子として注目されている 


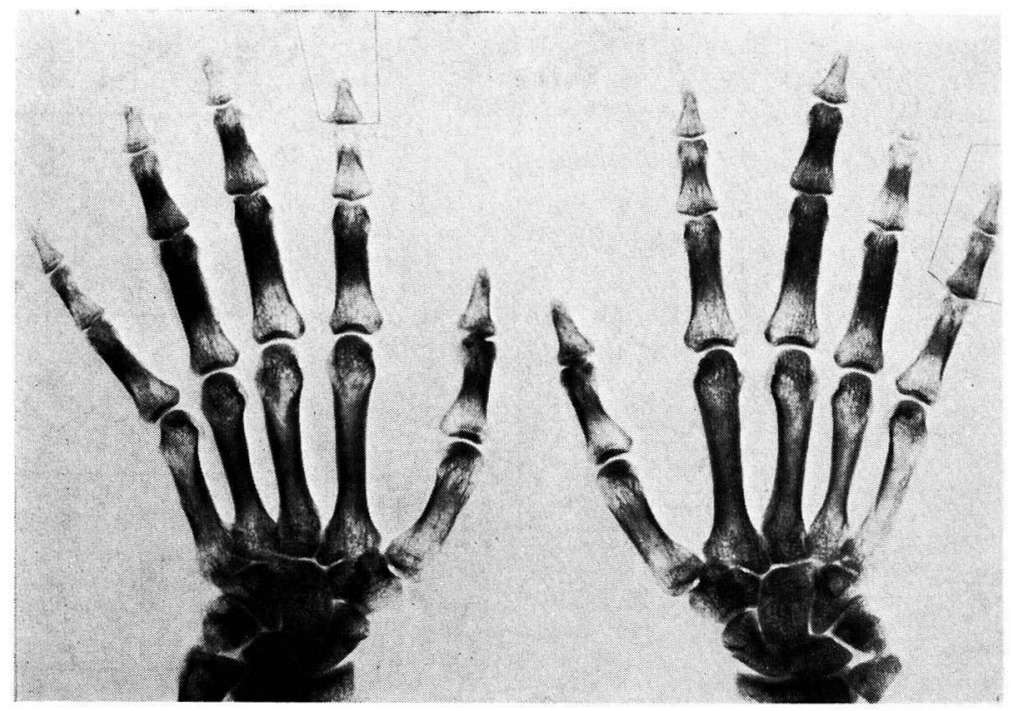

図 2 指骨の骨膜下吸収
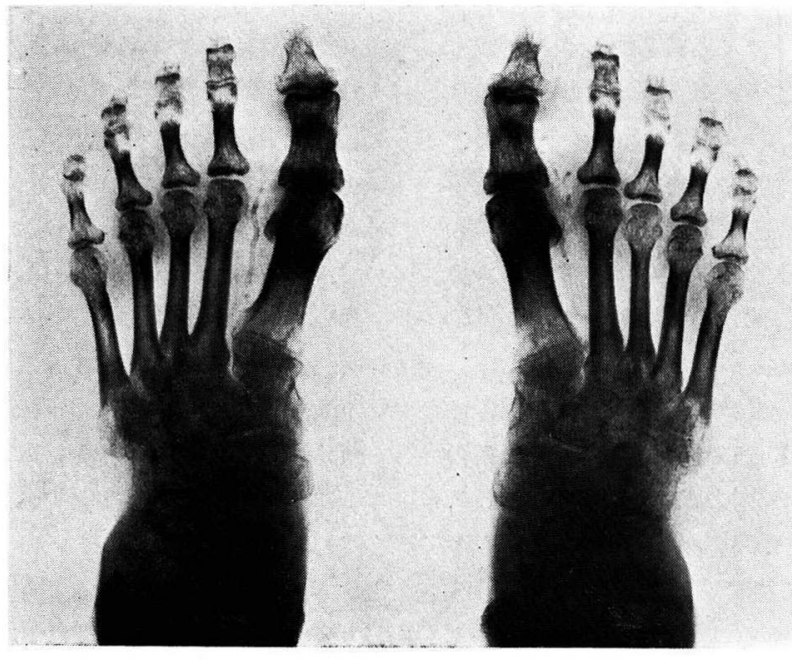

図 3 血管 の 石 灰沈着

が，ての他に多くの因子が複雑に組合さって発生する ものと推定される.

近年慢性腎不全に対し透析療法が応用されるように なり，患者の延命効果がもたらされると共に, renal osteodystrophy や転移性石厕化の発生力i多数の症例 に見られるととが報告されているが，乙れ等の合併症 は報告者により発生率に差異がみられ, 透析方法, 透 析時間, 尿毒症のコントロール方法等の差異によると されている.
透析により $\mathrm{Ca}$ を負荷して, $\mathrm{Ca}$ バランスを陽にす ると副甲状腺機能圥進症による骨の破壊が促進されず に remineralisation が起とるととが報告され，透 析液の $5.7 \mathrm{mg} / \mathrm{dl}$ 以下の 低濃度では骨変化の発生が 多いとされている. しかし適切なる透析液の濃度を決 定するととが望ましいととであるが，血清 $\mathrm{Ca}$ 濃度 を上昇せしめると血漿 $\mathrm{PO}_{4}$ 濃度が高い場合, 転移性 石灰化を起こし易いこと, また副甲状腺機能立進症が みられる症例では単に透析液の $\mathrm{Ca}$ 濃度を高めるの 


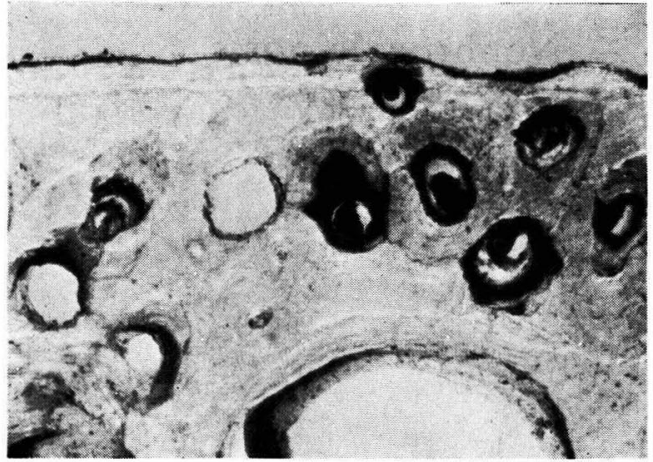

図4 助骨の横断面, osteochrome 染色 osteoid seam を伴った osteon と resorption cavityをみる. osteoid seam の巾が增加している.

みでは，このような骨変化は阻止できないと云われて いる.

長期透析症例に骨変化, 転移性石灰化等がしばしば 認められ，また osteoporosis 等の新しい骨障害が透 析により発生することが報告されている. その理由と して患者の生存期間の延辰あるいは透析自体に問題が あるとする $2 つ の$ 子があげられている.

以上の如く renal osteodyrtrophy の成因, 治療, 予防に関しては充分に解明されているとは云えず, 多 くの問題を残している.

\section{文献}

1) Fourman, P. et al.: Calcium Metabolism and the Bone. Blackwell. 1968 Oxford.
2) Frost, H. M.: Stain Techn., 33, 273, 1960.

3) Frost, H. M. : Clin. Orthop., 25, 175, 1962.

4) Frost, H. M.: J. Bone and Joint Surg. 48-A, 1192, 1966.

5）久貝ほか：代謝. $10,426,1973$.

6）小椋ほか：腎臟, Recent Advance Searies, 中山書店. 1973.

7) Nicholas, J. A.: J. Bone and Joint Surg., 45-A, 391, 1963.

8) Siddiqui, J. et al. : British Medical Bulletin. 27, 153, 1971.

9）若松ほか：整形外科. $15 ： 8,1964$.

\section{発 言北里大学 真角 昭吾}

(1) 今申された骨変化は, 慢性腎不全と血液透析の両 方の装因が加わったものである.

(2) 以前, 我々も大量のビタミンDにより骨変化は改 善されうる事を述べたが，最近のビタミン D代謝の 解明から, 腎がビタミン Dの最終的な代謝の場とし てクローズアップされている.これがため腎性骨症 のビタミン D治療には尚問題が多い。透析液の $\mathrm{Ca}$ 含有量を増加させるのも一法であろうし，また Dihydrotachysterol 投与による治療法む試みられ ている.

解 答整形 酒匂 崇

婜透析由来に関連する変化か, 腎自体の障害に関連 する変化かの推定は不明である, アルミゲル, Vit D 等の投与をしている. 